\title{
POSSIBILITIES OF BUILDING CONNECTION OF M.R. ŠTEFÁNIK AIRPORT TO THE ŽSR NETWORK
}

\begin{abstract}
The current conditions of the railway infrastructure near the M. R. Štefánik Airport is analysed as unsatisfactory. The current form of the railway infrastructure of the monitored area is not adapted to the creation of a suitable place for boarding and alighting of passengers. The point determined for boarding and alighting of passengers must be at a reasonable distance from the M. R. Štefánik Airport terminal. This distance must be able to be overcome by walking so that it is not necessary to use another mode of transport to move between these places. The article deals with the possibilities of connecting of M. R. Štefánik Airport to the ŽSR network. The basis for the proposal to connect M. R. Štefánik Airport with a suitable infrastructure ŽSR network within the framework of railway passenger transport is the determination of a suitable transfer point. One of the logical priorities is to place the transfer point as close as possible to the air transport terminal of the M. R. Stefánik Airport within the space possibilities and technical conditions. Keywords: ŽSR network, transfer point, M. R. Štefánik Airport, terminal of integrated passenger transport, track section
\end{abstract}

\author{
Zdenka Bulková ${ }^{1}$ \\ ${ }^{1}$ Faculty of Operation and Economics of Transport and Communications University of Žilina, \\ Univerzitná 8215/1,01026 Žilina; +421/41513 3406; zdenka.bulkova@fpedas.uniza.sk \\ Jozef Gašparík ${ }^{2}$ \\ ${ }^{2}$ Faculty of Operation and Economics of Transport and Communications University of Žilina, \\ Univerzitná 8215/1,01026 Žilina; +421/41 513 3430; jozef.gasparik@fpedas.uniza.sk \\ Vladislav Zitrický $\dot{y}^{3}$ \\ ${ }^{2}$ Faculty of Operation and Economics of Transport and Communications University of Žilina, \\ Univerzitná 8215/1,01026 Žilina; +421/41513 3406; vladislav.zitricky@fpedas.uniza.sk
}

\section{Introduction}

Rail transport which is located in the vicinity of the M. R. Stefánik Airport works only for the purpose of freight transport. It is primarily in the form of fuel imports, to which the given infrastructure is also adapted. The potential of the M. R. Štefánik Airport is not spent. The possibilities of access to this airport are considerably limited by the degree of development of individual types of infrastructure. The railway infrastructure that currently serves the needs of the M. R. Štefánik Airport exists in the form of a railway siding. It opens into the railway network by turning the airport onto a non-electrified single-track line, which leads to the Podunajské Biskupice railway station. At present, not much is expected to be used for passenger transport purposes. This is mainly the distance from the airport terminal, while the advantage is not even the mouth of the railway network. A justified step is the analysis of the possibilities of connecting the M. R. Štefánik Airport to the ŽSR railway network and to prepare a proposal for the routing of the relevant infrastructure. The proposed infrastructure will be suitable for the purposes of passenger transport with an adequate level of comfort, quality and safety. This step must be in particular in accordance with the Railways Act 513/2009 Coll. and Decree 350/2010 Coll. on the construction regulations of railways. For the purpose of the proposal, it is necessary to pay attention to the conditions specified in the Aviation Act 143/1998 Coll., which will meet the conditions for the completion of the proposal itself. (Čechovič, et. al., 2020). In their research, transport service around the airport and to the airport was solved by Čechovič, L. et. al. (2020), who examined the transport service of Ostrava Airport in the Czech Republic. A similar issue was dealt with by Černá, L. et. al (2018), Zitrický, V. et. al. (2020) who dealt with Comparative analysis in terms of environmental impact assessment between railway and air passenger transport operation. The sustainability of transport in the Danube region, where the M. R. Stefánik Airport is located, was addressed in his research Mako, P. et. al. (2021).

\section{Characteristics of the railway network of Slovakia and M. R. Štefánik Airport}

The current railway infrastructure in the territory of the capital of the Slovak Republic is conceived as an important transport hub. This hub consists of several interconnected European important lines also included in the TEN, AGC and AGTC networks. (Zitrický, et. al., 2020). Transregional main railway lines marked according to sections in the Slovak territory from the tables of line conditions of ŽSR pass through the area radially in the following directions (BSK, 2012):

- 126 A: Bratislava - Brno - Prague - Dresden - Berlin - Hannover,

- 125 A: Bratislava - Žilina - Čadca - Zwardoň Warsaw - Gdańsk,

- $\quad 120$ A: Bratislava - Štúrovo - Budapest - Belgrade Istanbul - (Thessaloniki).

The Bratislava railway junction has a standard track gauge of 1435 millimetres. It consists of individual sections with a total length of 100.7 kilometres, of which 49.5 kilometres are double-track and the other length 
consists of single-track sections. Of the total length of track sections, 86.6 kilometres are electrified by a singlephase AC supply system of $25 \mathrm{kV}$ and $50 \mathrm{~Hz}$. (Černá, et. al., 2018). The railway infrastructure currently serving the needs of M.R. Štefánik Airport, exists in the form of a railway siding, which is connected to the railway network by a branch airport, according to Figure 1, on a nonelectrified single-track line leading to the Podunajské Biskupice railway station. This siding is used to supply loaded wagons with oil products. These are mainly aviation fuels and the subsequent removal of empty wagons. (Mako, et. al., 2021)

At present, not much is expected to be used for passenger transport purposes. This is mainly the distance from the airport terminal, while the advantage is not even the mouth of the railway network. Figure 1 shows the current connection of the airport siding to the ŽSR network. M. R. Štefánik Civil Airport - Airport Bratislava has a 24hours operation. This airport was established in 1951 and is situated near the city of Bratislava with a distance of 9 kilometres northeast of the city centre.

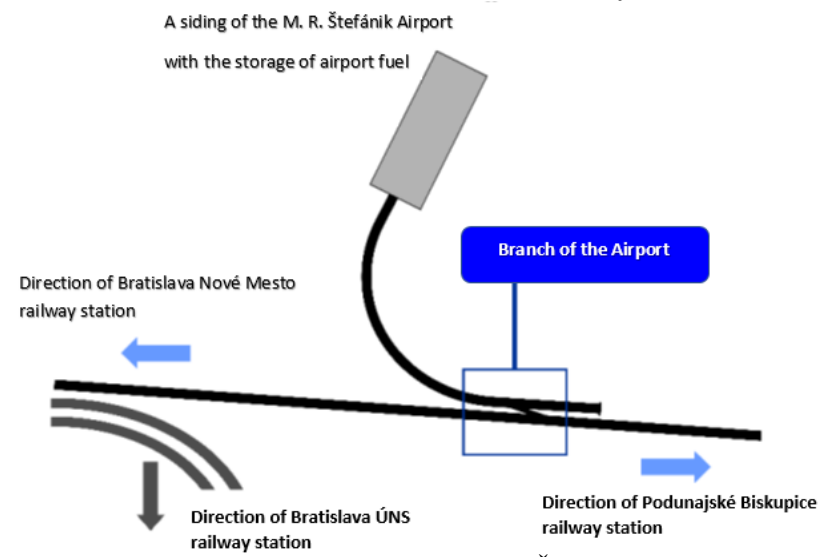

Fig 1. Connection of the siding of M. R. Štefánik Airport to the railway network (Source: Remeň, 2019)

There are currently two runways with a concrete surface in operation (Figure 2). The main track is 2950 metres long and 45 metres wide. It is marked with data $13 / 31$, which determine the direction of travel according to the magnetic azimuth. The side runway $04 / 22$ is 2900 metres long and 60 metres wide. The intersection point is 904 metres from runway 13 and 1428 metres from runway 04. The airport's check-in area, with an area of 143,000 $\mathrm{m}^{2}$, has 33 marked aircraft stands. (BTS, 2018)

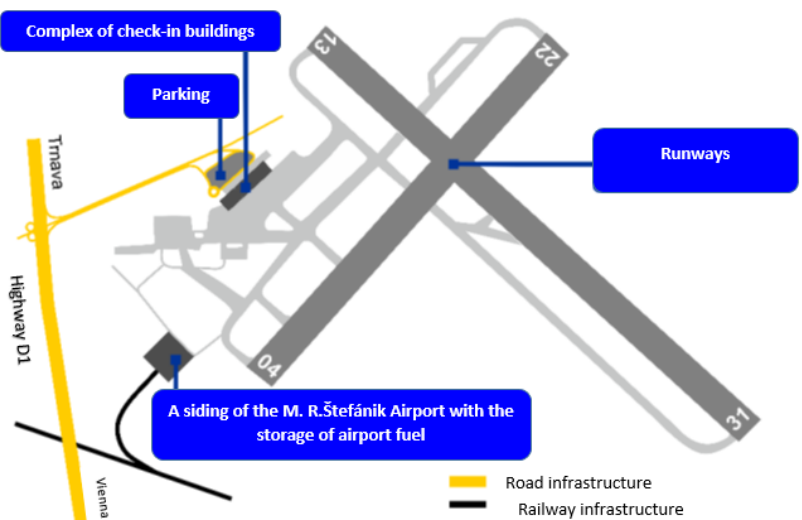

Fig 2. Schematic representation of the layout of the M. R. Štefánik Airport (Source: Remeň, 2019)

The location of the complex of three consecutive terminal check-in halls is schematically shown in Figure 2. Its total area is $48,545 \mathrm{~m}^{2}$ with an estimated capacity of 5 million passengers handled per year. Figure 2 also shows the existing infrastructure around the airport. We can also see that the different distance between the location of the railway infrastructure and also the road infrastructure to the terminal is demonstrated. Between the terminal and car parks $\mathrm{P} 1$ and $\mathrm{P} 2$, there are parking slots for taxi services and bus transport. (BTS, 2018)

\section{Position of the transfer point between M. R. Stefánik Airport and the railway infrastructure}

The basis for the proposal to connect M. R. Štefánik Airport with a suitable infrastructure to the ŽSR network within the framework of railway passenger transport is the determination of a suitable transfer point. One of the logical priorities is to place the transfer point as close as possible to the air transport terminal of the M. R. Stefánik Airport within the space possibilities and technical conditions.

The basic dispositional possibilities of the location of the railway infrastructure are shown in Figure 3 together with a map of the area around the complex of check-in buildings of the M. R. Śtefánik Airport processed at a scale of 1: 5,000. Here is shown the spatial radius, which is centred in the plane of the entrances of the airport terminal. This radius consists of two distance zones 250 and 500 metres. The plane shown divides the radius and semicircle that arose naturally beyond this plane and cannot be classified as an area in which the railway infrastructure can be located. The first zone of 250 metres limits the maximum distance when planning the terminal of integrated passenger transport, which is overcome by walking between the platform and the place of transfer to another mode of transport. The standard is a distance of about 50 metres. The zone up to 500 metres was chosen within the current spatial situation around the M. R. Štefánik Airport with an impact on open and undeveloped areas. In this case, the location of the railway platform should not be considered as part of the terminal of integrated transport, but only as a railway station or a railway station close to the airport. However, the aim of 
designing attractive connections and promoting public rail transport would not have to be achieved to the extent expected. The reason is the immediate distance before entering the complex of check-in buildings, where bus stops, taxi ranks and car parks for individual car transport have already been set up.

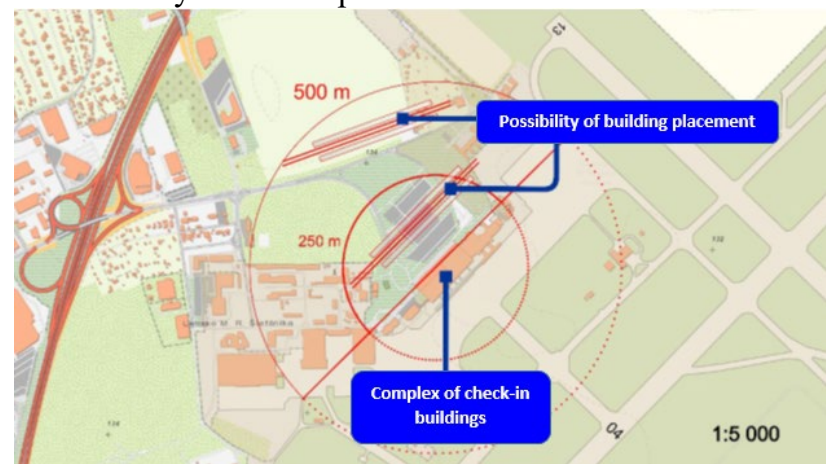

Fig 3. Spatial radius of the possibility of position the transfer point from railway transport (Source: Remeň, 2019)

The final location of the railway station, which as a part of the transport of integrated passenger transport of the M. R. Štefánik Airport includes the above-mentioned conditions of attractiveness. Due to the spatial possibilities, this is a sub-level variant of routing the railway infrastructure of the planned station.

The advantages of the proposed solution include

- $\quad$ out of level crossing with roads around the airport,

- minimum distance to the airport terminal,

- $\quad$ straight 400 metres long and 550 millimetres above the top of the track high standardized platforms,

- the possibility of excavating the area with excavation work for placement above the undeveloped area (except for the temporary abolition of the car park),

- better possibilities of connection with the ŽSR network by sections with higher track speed,

- terrain and subsoil in the construction area,

- less impact on the character of the landscape and the city after completion.

At the same time, these solutions also bring disadvantages in the form of:

- higher construction costs,

- technological complexity of construction in comparison with the location on the surface,

- $\quad$ operating costs.

3. Possibilities of connecting the terminal of the integrated passenger transport of the M. R. Štefánik Airport to the ŽSR network

There are a total of three possibilities for connecting the terminal of the integrated passenger transport of the M. R. Štefánik Airport to the existing railway infrastructure of ŽSR. It is justified to compare and consider their advantages alone or in combination with each other. According to ŽSR track condition tables, suitable interstation sections are $120 \mathrm{~A}$ track section between the Bernolákovo railway station and the Močiar branch in both directions, 127C track section between the Bratislava -
Nové Mesto and Bratislava - ÚNS railway stations also in both directions, and 124A track section towards the Podunajské Biskupice railway station, current siding to the airport.

\subsection{Connection to the ŽSR 120A track section}

The planned single-track line section is 3.3 kilometres away from the integrated passenger transport terminal of the M. R. Štefánik Airport, which is directed from the Močiar branch and is electrified along its entire length by a $25 \mathrm{kV}$ and $50 \mathrm{~Hz}$ supply voltage system.

It is connected to the main track ŽSR $120 \mathrm{~A}$ at kilometres 62,797 in front of the railway station Bratislava - Vajnory. This section is called BTS A in this article (Figure 4). It leads through an almost undeveloped area and crosses the level of the D1 highway section (E75), the motorway road I / 61 and the local road Overpass of Vajnory below ground level. Routing is different from the Traffic-urban study of the original TEN - T 17 project of the airport connection from 2009. According to this study, the route was to be connected to the ŽSR 120A track section behind the Bratislava - Vajnory railway station.

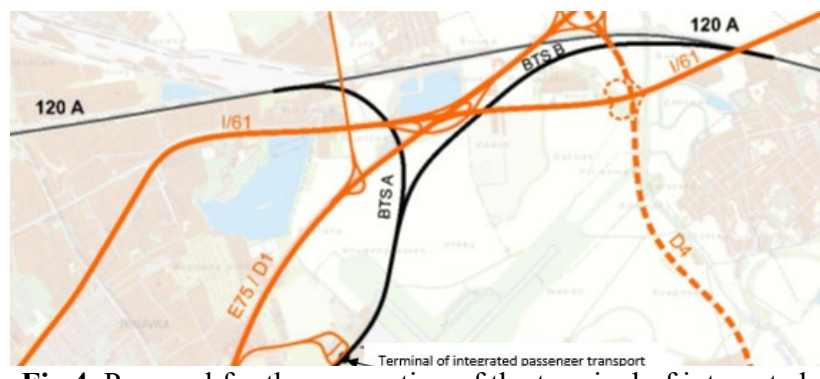

Fig 4. Proposal for the connection of the terminal of integrated passenger transport of the M. R. Štefánik Airport to the ŽSR 120A track section (Source: Remeň, 2019)

A visual illustration of routing BTS A track sections shown at a 1: 25,000 scale map in Figure 4. Here we can see the overall spatial possibilities of routing this section. The problem is the space in the gardening area at the Overpass Vajnory and at the Zlaté Piesky rest area. The route is led from the ground level from the place of connection, where possible, and also in the cuts to the airport from where it continues through the tunnel to the terminal of the integrated passenger transport of the M. R. Štefánik Airport.

An overall assessment of the benefits as well as the negative effects of the construction of the BTS A section is given in Table 1. A disadvantages arise especially in the construction phase. In principle, they have a negative impact on the construction of all alternatives. The permanent negative effect is the occupation of arable land in the area and further spatial division of the area by a line led mostly in notches. (ŽSR, 2019) 
Table 1. Assessment of the effects of the construction of the BTS A track section; (Source: Remeň, 2019)

\begin{tabular}{|l|}
\hline Advantages of the BTS A track section \\
\hline $\begin{array}{l}\text { Connection to the main double-track electrified line (track } \\
\text { speed currently up to } 120 \mathrm{kph} \text { ). }\end{array}$ \\
\hline $\begin{array}{l}\text { Ongoing modernization and electrification of the track on the } \\
\text { Austrian side with a line speed of } 200 \mathrm{kph} .\end{array}$ \\
\hline $\begin{array}{l}\text { Electrification of the railway station Devinska Nová Ves - state } \\
\text { border in the phase of project preparations. }\end{array}$ \\
\hline $\begin{array}{l}\text { In this alternative, the direct connection route leads through the } \\
\text { busy transfer node of the Bratislava main station. }\end{array}$ \\
\hline $\begin{array}{l}\text { Possibility of direct connection of the airport with the lowest } \\
\text { construction costs. }\end{array}$ \\
\hline $\begin{array}{l}\text { Tracing is in a minimally built-up area and this is associated } \\
\text { with the technological complexity of construction. }\end{array}$ \\
\hline Line speed of this section at least 100 kph. \\
\hline Disadvantages of the BTS A track section \\
\hline $\begin{array}{l}\text { Local drops of maximum line speed on the current } \\
\text { infrastructure up to } 30 \text { kph. }\end{array}$ \\
\hline $\begin{array}{l}\text { Current use of infrastructure capacity between the Bratislava } \\
\text { main station and the Devínska Nová Ves railway station. }\end{array}$ \\
\hline Occupancy of agricultural land. \\
\hline $\begin{array}{l}\text { Restrictions on traffic during construction on important roads } \\
\text { and main roads. }\end{array}$ \\
\hline Increased noise and dust levels during construction. \\
\hline
\end{tabular}

At present, the importance of this route will increase significantly due to the planned electrification of the adjoining track section or the addition of a second line track and also a comprehensive modernization along the Devínska Nová Ves railway station. This can be included in the advantages of building the BTS A track section. The strategic development of the Bratislava transport hub, which is based mainly on the ŽSR Feasibility Study from 2019, would also contribute to minimizing these disadvantages. The advantage of building this section may increase in combination with the alternative of connecting the BTS C track section. This will create the possibility of using the infrastructure "loop" in the Bratislava transport hub for trains leading to the Bratislava - Nové Mesto railway station from the direction of Trnava and Malacky.

Figure 4 shows the connection of the terminal of integrated passenger transport of the M. R. Štefánik Airport to the marked BTS B track section. This track section leads from the Bernolákovo railway station and is connected to the line called ŽSR $120 \mathrm{~A}$ at kilometres 67,500 . This track section is intended as double track and electrified. The track section is run at ground level, while the crossing with the D4 and I / 61 roads is solved off-level.

The BTS B track section is connected to the BTS A track section at the level of the Zlate Piesky rest area. From there, together with BTS A, it will be led through a tunnel as a double-track section to the terminal of integrated passenger transport of M. R Štefánik Airport. The planned BTS B track section is justified within the framework of passenger transport to the airport. Therefore, it will be considered as a development variant within the subsequent stages of the construction of the railway infrastructure to connect the planned terminal of integrated passenger transport of the M. R. Štefánik Airport.
Table 2. Assessment of the effects of the construction of the BTS B track section; (Source: Remeň, 2019)

\section{Advantages of the BTS B track section}

It will create a parallel route to the ŽSR $120 \mathrm{~A}$ track section in combination with the BTS C track section.

It will be possible to connect the terminal of integrated passenger transport of the M-R. Štefánik Airport, the Bratislava - Nové Mesto railway station, and the Bratislava main station in combination with the BTS C track section. This makes it possible to increase their attractiveness and use in international and regional passenger transport.

An infrastructure "loop" suitable for trains leading to the Bratislava - Nové Mesto railway station from the direction of Senec will be created with the BTS C track section.

\section{Disadvantages of the BTS B track section}

Occupancy of agricultural land.

Restrictions during construction, as for BTS A track section.

The proposed BTS B track section is 4.2 kilometres long. It is also justified when transporting people not only to the airport. The elaborated table 2 shows the influences caused by the construction of this section. Nevertheless, it is a development variant within the purpose of building infrastructure. This section shows the greatest benefits in combination with the BTS C track section. With the appropriate routing of international trains, a connection will be established between Budapest, M. R. Štefánik Airport by means of the terminal of integrated passenger transport, as well as the cities of Bratislava and Prague. The potential of the Bratislava - Nové Mesto railway station will increase, which will also be a connecting hub in regional transport or urban public transport. The condition for this positive impact of these sections is to increase the capacity of the track section referred to as ŽSR $127 \mathrm{G}$ between the Bratislava - Nové Mesto railway station and the Bratislava main station by adding a second track. This recommendation is also supported by the feasibility study of the Bratislava transport hub from 2019 based on an analysis of the current situation.

\subsection{Connection to the ŽSR 127C track section}

Another suitable point of connection of the terminal of integrated passenger transport of M. R. Štefánik Airport to the existing railway infrastructure is $127 \mathrm{C}$ track section. Several studies have been devoted to the construction of railway infrastructure for the purposes of the airport. The traffic-urban study of the TEN-T 17 project from 2009 assumed the construction of railway infrastructure, which is connected to the ŽSR $127 \mathrm{C}$ track section in both mentioned directions. The connection from the direction of the railway station Bratislava - ÚNS was to be realized by a bridge structure at the place where the track in front of the airport descends. It continues in the tunnel together with the branch from the direction of the Bratislava - Nové Mesto railway station to the underground station, which is located at the airport. The connection ideas from this study remain. These two connection alternatives not only from the Bratislava - Nové Mesto railway station, but also from the direction of the Bratislava - ÚNS railway station have 
a justification with demonstrable potential. These alternatives are referred to as BTS C and BTS D sections for clarity. This designation and routing of the sections is shown on a 1:25,000 map in Figure 5.

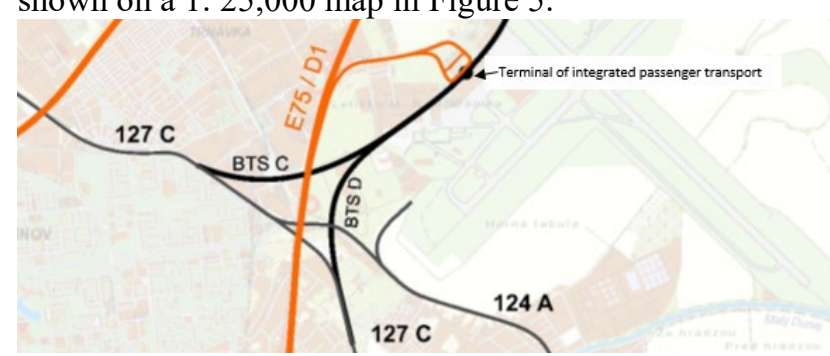

Fig 5. Spatial radius of the possibility of position the transfer point from railway transport (Source: Remeň, 2019)

Due to the extensive urban construction in the planned route, the BTS C track section is 2.3 kilometres long and is routed below ground level. In the current construction with the BTS B track section, it is suitable to build these sections with two tracks. This creates a highquality and parallel section with the original track section called ŽSR $120 \mathrm{~A}$ with the advantages described above. In the case of independent construction, it is possible to consider this section as a single track, without considering a change in the route of some passenger trains from $120 \mathrm{~A}$ track section. With these two options, the point where called $127 \mathrm{C}$ track section connects should reflect the planned development of not only this section. It should also take into account the part of the city routed in parallel on the track section referred to as $124 \mathrm{~A}$ track section to the Podunajské Biskupice railway station.

The feasibility study of the Bratislava transport hub from 2019 recommends an increase in capacity and the addition of a second track as part of the development of these existing track sections and, in particular, the section designated as 124A. Among other things, the construction of the terminal of integrated passenger transport called Ružinov is planned in the area of Vrakuňa road. The construction of platforms and adjustment of the geometric position of the tracks is planned here. As part of increasing the capacity of the track designated as $124 \mathrm{~A}$ in the interstation section in question, the construction of a new transport station in the form of the Ružinov branch is proposed, which is recommended in each alternative. (ŽSR, 2019)

These proposals are therefore followed by the planned section of BTS C. This section should be connected to the current railway infrastructure in the planned branch of Ružinov. The routing does not necessarily have to include the Ružinov terminal of integrated passenger transport due to the nature of the passenger transport to the airport. Table 3 shows the advantages and disadvantages of the construction of BTS C track section.

Table 3. Assessment of the effects of the construction of the BTS C track section; (Source: Remeň, 2019)

\begin{tabular}{l}
\hline Advantages of the BTS C track section \\
$\begin{array}{l}\text { The advantages are identical in combination with the BTS B } \\
\text { track section. }\end{array}$ \\
\hline
\end{tabular}

Possibility of direct connection with other airports.

When building independently, the route of the planned connection will also include the Bratislava - Nové Mesto railway station.

Disadvantages of the BTS C track section

Capacity of the inter-station section between Bratislava main station and Bratislava - Nové Mesto railway station.

Higher cost and construction difficulty compared to BTS A track section.

The difference between the benefits of the BTS C track section and the BTS A track section lies in the method of routing the planned connection through the Bratislava - Nové Mesto railway station. These alternatives have other advantages in common. The disadvantage of the section is that the entire length of the section routing is below ground level and below the builtup urban area. This significantly increases construction costs and the overall complexity of construction. Most of the existing disadvantages of routing a planned connection through Marchegg are common to these two BTS A and BTS C alternatives. The second possibility is disadvantaged by the restrictive section of Bratislava main station and Bratislava - Nové Mesto railway station. This inter-station section is currently the busiest section of the Bratislava railway junction. (ŽSR, 2019)

The condition for balancing the effects of sections BST A and BTS C is the construction of a second track in this restrictive section. The method of connection of the terminal of integrated passenger transport of the M. R. Štefánik Airport from the track section marked as ŽSR $127 \mathrm{C}$, which leads to the railway station Bratislava - ÚNS, is shown in Figure 5. This BTS D track section is shown here. It is routed below the ground level from the terminal of integrated passenger transport. It continues to the track section designated $127 \mathrm{C}$. Here it is fed in the area of $\mathrm{Na}$ piesku street at 9,200 kilometres. Below track 124A and Vrakuňa road, the routing was chosen below ground level due to the slope conditions. The single- BTS D track section is planned in the same way as the previous sections as electrified by the standard $25 \mathrm{kV} 50 \mathrm{~Hz}$ power supply system. The illustration of the effects of the construction of the BTS D track section in the length of 2.15 kilometres is shown in Table 4.

Table 4. Assessment of the effects of the construction of the BTS D track section; (Source: Remeň, 2019)

Advantages of the BTS D track section

Possibility of direct connection of M. R. Štefánik Airport with Vienna Airport.

The existing connection infrastructure is fully electrified.

Disadvantages of the BTS D track section

Technologically and economically demanding section for construction.

Technical condition of the connected infrastructure to the Bratislava - Petržalka railway station.

The disadvantages of building a separate BTS D track section are mainly high investment costs in the 
construction of this section and the modernization of the adjoining infrastructure to the Bratislava - Petržalka railway station. By eliminating them, this planned section would significantly increase its importance. This would also be dramatically increased by the planned construction of a railway line between Wien Flughafen and Bruck a. d. Leith in order to increase the capacity of the current Ostbahn between Vienna and Budapest. With the construction of this track section, the Wien Flughafen station would be connected to the TEN - T network by a high - performance line. This will make it possible to adjust the routing of passenger trains through this important transfer point. (ÖBB, 2017)

These include, for example, trains from the track between Wien hbf and the Bratislava - Petržalka railway station, which could thus be extended to the terminal of integrated passenger transport of M. R. Štefánik Airport. It would be possible to create a connection between the main station in Vienna, Vienna Airport and M. R. Štefánik Airport. During the simultaneous construction of BTS D and BTS A track sections, it will be possible to extend such a connection to the Bratislava main station. The maximum possibility of designing a railway connection, which is conditioned by the existence of infrastructure formed by BTS A and BTS D track sections, is the Bratislava Vienna ring road.

\section{Conclusion}

The investigated alternatives are not mutually exclusive and each of these planned sections represents its own special contribution with regard to the purpose of connecting the terminal of integrated passenger transport of the M. R. Stefánik Airport. The synergistic effect of combining these track sections significantly increases the value of their separate benefits. Therefore, it is appropriate to consider these planned sections as individual stages of the development of railway infrastructure at M. R. Štefánik Airport, rather than separate alternatives. They need to be classified according to a set priority level. The level of priority construction of these sections is shown in Table 5, where the level is based on a modified analysis of the management of the company's internal environment. This is supplemented by the scale of individual factors.

Due to the difference in the effects of these factors on these track sections, a significance scale in the range of 1 10 was chosen in the assessment. The evaluation of a section for a specific factor on a scale of $1-5$ is multiplied by the weight so that its significance is taken into account. Number 5 in the rating means the best rating and number 1 means the worst rating. The resulting sum of points will determine the significance of the assessed track sections to the terminal of integrated passenger transport of M. R. Štefánik Airport. Emphasis was placed on the complexity of construction when choosing the scale in comparison with the immediate benefit and the lowest conditional requirements for the modification of the current infrastructure.
The analysed influences and effects of the construction of these track sections from the terminal of integrated passenger transport of M. R. Štefánik Airport, which are connected to the ŽSR network, show, according to Table 5, a different level of significance, due to the current form of infrastructure. This ratio will change significantly when considering the planned development of existing infrastructure. Due to the complexity of the construction and the immediate benefits after the construction of a separate section, the BTS A track section becomes a priority.

This is the basic stage of the construction of the railway infrastructure to the $M$. R. Štefánik Airport. The BTS D track section will receive significant justification after the construction of the line on the Austrian side between Wien Flughafen and Bruck a.d. Leith. At present, the BTS A section does not outperform its benefits, mainly due to construction technology and the need to introduce new passenger trains.

At present, the Wien hbf and Wien Flughafen railway stations cannot be operated directly, as is the case with the BTS A, with dead ends causing time losses. Therefore, section BTS D is considered to be the first development stage of the basic scheme of railway infrastructure in the vicinity of M. R. Štefánik Airport. Along with this section, a BTS C track section is also planned below ground level, which should be built at the same time as BTS D track section. Especially under the condition of building the second track of the inter-station section called ŽSR 127G. The considered section BTS B is semantically connected with the section BTS B. It is justified within the stages of development only in the final phase. The final phase will complete a total of 11.7 kilometres of new lines connected to the ŽSR network within the Bratislava transport hub.

Based on the analysis of the possibilities of connecting the M.R. Štefánik Airport to the ŽSR railway network, it is necessary to build an underground railway station in the parking area below ground level in the initial phase of construction. It will become part of the terminal of integrated passenger transport. It will be connected in the first stage to the ŽSR network and will be the construction of a single-track section. This section will have a total length of 3,342 kilometres and will be electrified by an alternating supply voltage system of $25 \mathrm{kV}, 50 \mathrm{~Hz}$, including the said railway station. This section will have a track speed of up to $160 \mathrm{kph}$ and will be routed from the terminal of integrated passenger transport of the M. R. Štefánik Airport via the left bend. The left bend will have a radius of 1200 metres and an elevation of 126 millimetres of rails into a straight section with a length of 715 metres. This straight section is followed by a second, again left, bend with a maximum track speed reduced to $100 \mathrm{kph}$, a radius of 810 metres and an elevation of 88 millimetres. It opens into the track section called ŽSR 120A at kilometres 62,797 and in the perimeter of the Bratislava - Vajnory railway station. 
Table 5. Critical factors of prioritizing the planned sections of the connection of the terminal of integrated passenger transport of the M. R. Štefánik Airport (Source: authors)

\begin{tabular}{|c|c|c|c|c|c|c|c|c|c|c|}
\hline $\begin{array}{l}\text { Evaluation of a section for a specific } \\
\text { factor }\end{array}$ & 1 & 2 & 3 & 4 & 5 & Scale & BTS A & BTS B & BTS C & BTS D \\
\hline \multicolumn{7}{|c|}{$\begin{array}{l}\text { 1. Attractiveness of the track section of the connection of the terminal of } \\
\text { integrated passenger transport of the M. R. Stefánik Airport within the } \\
\text { passenger transport }\end{array}$} & 352 & 250 & 329 & 331 \\
\hline $\begin{array}{l}\text { The current overall potential for the use of } \\
\text { the track section }\end{array}$ & B & & & \begin{tabular}{|l|} 
A \\
C \\
$\mathrm{D}$
\end{tabular} & & 10 & 40 & 10 & 40 & 40 \\
\hline $\begin{array}{l}\text { Prospective total potential for the use of the } \\
\text { track section }\end{array}$ & & & $\begin{array}{l}\mathrm{A} \\
\mathrm{C}\end{array}$ & $\begin{array}{l}\mathrm{B} \\
\mathrm{D}\end{array}$ & & 8 & 24 & 32 & 24 & 32 \\
\hline $\begin{array}{l}\text { The potential for connecting M. R. Stefänik } \\
\text { Airport and other airports }\end{array}$ & B & & & & $\begin{array}{l}\text { A } \\
\text { C } \\
\text { D }\end{array}$ & 8 & 40 & 8 & 40 & 40 \\
\hline Potential use of the track section separately & B & & & $\mathrm{c}$ & $\begin{array}{l}\mathrm{A} \\
\mathrm{D}\end{array}$ & 7 & 35 & 7 & 28 & 35 \\
\hline $\begin{array}{l}\text { Potential use ofthe track sections in } \\
\text { combination }\end{array}$ & & & & \begin{tabular}{|l|} 
A \\
$\mathrm{D}$
\end{tabular} & \begin{tabular}{l|l}
$\mathrm{B}$ \\
$\mathrm{C}$
\end{tabular} & 5 & 20 & 25 & 25 & 20 \\
\hline \multicolumn{11}{|c|}{ 2. Technical condition of the connected infrastructure during the design of the airport connection route } \\
\hline $\begin{array}{l}\text { Current overall condition (electrification, } \\
\text { etc.) }\end{array}$ & & & A & \begin{tabular}{l|} 
B \\
C \\
D \\
\end{tabular} & & 5 & 15 & 20 & 20 & 20 \\
\hline Impact of ongoing projects & $\begin{array}{l}\mathrm{B} \\
\mathrm{D}\end{array}$ & & & & $\begin{array}{l}\mathrm{A} \\
\mathrm{C}\end{array}$ & 2 & 10 & 2 & 10 & 2 \\
\hline $\begin{array}{l}\text { Planned overall condition (electrification, } \\
\text { etc.) }\end{array}$ & & B & $\begin{array}{l}\mathrm{C} \\
\mathrm{D}\end{array}$ & A & & 5 & 20 & 10 & 15 & 15 \\
\hline Current capacity of the track sections & $\mathrm{C}$ & $\begin{array}{l}\text { A } \\
B \\
D\end{array}$ & & & & 8 & 16 & 16 & 8 & 16 \\
\hline Planned capacity of the track sections & & & $\mathrm{D}$ & $\begin{array}{l}\text { A } \\
\mathrm{B} \\
\mathrm{C}\end{array}$ & & 5 & 20 & 20 & 20 & 15 \\
\hline Current technical speed & & & $\begin{array}{l}\mathrm{C} \\
\mathrm{D}\end{array}$ & $\begin{array}{l}\mathrm{A} \\
\mathrm{B}\end{array}$ & & 7 & 28 & 28 & 21 & 21 \\
\hline Planned technical speed & & & & $\mathrm{C}$ & $\begin{array}{l}\mathrm{A} \\
\mathrm{B} \\
\mathrm{D}\end{array}$ & 4 & 20 & 20 & 16 & 20 \\
\hline \multicolumn{11}{|c|}{$\begin{array}{l}\text { 3. Construction of the track sections connecting the terminal of the integrated passenger transport of the M. R. Stefánik } \\
\text { Airport }\end{array}$} \\
\hline Technological complexity of construction & $\begin{array}{l}\mathrm{C} \\
\mathrm{D}\end{array}$ & & & $\mathrm{B}$ & $\mathrm{A}$ & 7 & 35 & 28 & 7 & 7 \\
\hline Occupancy of agricultural land & & $\begin{array}{l}\mathrm{A} \\
\mathrm{B}\end{array}$ & & $\mathrm{D}$ & $\mathrm{C}$ & 7 & 14 & 14 & 35 & 28 \\
\hline $\begin{array}{l}\text { Permanent impact of the section on the } \\
\text { surroundings }\end{array}$ & & B & A & \begin{tabular}{l|l}
$\mathrm{D}$ \\
$\mathrm{C}$
\end{tabular} & & 5 & 15 & 10 & 20 & 20 \\
\hline
\end{tabular}

\section{Acknowledgment}

„This work was supported by the Slovak Research and Development Agency under the Contract no. APVV-190444."

\section{References}

BTS.AERO, 2012 Annual Report of M. R. Štefánik Airport Airport Bratislava, a.s. Available: https://www.bts.aero/oletisku/press/rocne-spravy/ >

[Accessed 3 September 2021].

BTS.AERO, 2018 Annual report of BTS. Available: https://www.bts.aero/downloads/rocne-spravy/rocna-sprava2018.pdf?u=1>

[Accessed 3 September 2021].

Čechovič, L., et. al. 2020 Proposal transport services airport Leoš Janáček Ostrava. In: Transport technic and technology [electronic]. - ISSN 2585-8084 (online). - Roč. 16, č. 2 (2020), s. 16-20 [online].

Černá, L., et. al. 2018 Capacity of main railway lines - analysis of methodologies for its calculation. In: Naše More = Our Sea: znanstveni časopis za more i pomorstvo: international
Journal of Maritime Science \& Technology. - ISSN 1848-6320 (online). - Roč. 65, č. 4 (2018), s. 213-217.

Mako, P., et. al. 2021 Sustainable transport in the Danube. In: Sustainability [electronic]. - ISSN 2071-1050 (online). - Roč. 13, č. 12 (2021), s. [1-21] [online]. Available: https://www.mdpi.com/2071-1050/13/12/6797

ÖBB, 2017 Environmental report. Modification of the national transport network, Declaration of the railway line "Vienna Flughafen Wien (Vienna Airport) - Bruck / Leitha - State border near Nickelsdorf" as a high-performance route. Available: https://www.bmk.gv.at/dam/jcr:3dd3b444-2223426c-a4d1-a23ebfb9dacb/umweltbericht_slowakisch.pdf [Accessed 15 September 2021].

Remeň, L. 2019 Design of a railway connection between the airports of M. R. Štefánik - Airport Bratislava, a. s. and Flughafen Wien AG. Žilina, University of Žilina, 71 p.

Zitrický, V., et. al. 2020 Comparative analysis in terms of environmental impact assessment between railway and air passenger transport operation [electronic: a case study. In: International Journal of Sustainable Aviation [print, electronic]. - ISSN 2050-0467. - Roč. 6, č. 1 (2020), s. 21-35.

ŽSR, 2019 Feasibility study - ŽSR, transport hub Bratislava. Available: https://www.zsr.sk/modernizacia-trati/studierealizovatelnosti/uzol-bratislava.html > [Accessed 3 October 2021] 